редактори); І.О.Покаржевська (художнє оформлення). Київ, 2002. 742с. С.569; С. 88.

4. Данильян О. Г., Тараненко В. М.. Філософія: підручник, 2-ге вид., допов. і переробл. Харків, 2012. 312 c. C.5-12.

\section{REFERENCES}

1. Bekh,I.D. (2015). Vybrani naukovi pratsi. Vykhovannia osobystosti [Selected scientific works. Personal education]. Volume 1. Chernivtsi, 2015.840 p. P. 399 [in Ukrainian].

2. Bystrytskyi, Ye. K. (1996). The philosophical image of culture and the world of national being [Filosofskyi obraz kultury ta svit natsionalnoho buttia]. The phenomenon of Ukrainian culture: methodological foundations of understanding. Kyiv, pp.62-90; 465-467. [in Ukrainian].

3. Didenko, V. \& Tabachkovsky, V. (2002). Svitohliad [World outlook]. Encyclopedic Dictionary of Philosophy. V.I. Shynkaruk (Head of the Editorial Board), etc .; L.V. Ozadovskaya, N.P.Polischuk (scientific editors); I.O.Pokarzhevskaya (decoration). Kyiv, 742 p. P.569; 88 p. [in Ukrainian].

4. Danilyan, O. H., \& Taranenko, V. M. (2012). Filosofiia: pidruchnyk [Philosophy: a textbook]. 2nd ed., Suppl. and recycling. Kharkiv, 312 p. pp.5-12. [in Ukrainian].

Стаття надійшла до редакції 16.12.2019

УДК 78.071.1(477):37.01(477.83/.86)

DOI:

Іван Фрайт, кандидат педагогічних наук, доцент кафедри народних музичних інструментів та вокалу Дрогобицького державного педагогічного університету імені Івана Франка

Свгенія Шуневич, доцент кафедри народних музичних інструментів та вокалу Дрогобииького державного педагогічного університету імені Івана Франка

\title{
ВНЕСОК АНАТОЛІЯ ВАХНЯНИНА У РОЗВИТОК МУЗИЧНОЇ ОСВІТИ СХІДНОЇ ГАЛИЧИНИ
}

У статті виявлено внесок Анатолія Вахнянина у розвиток музичної освіти Східної Галичини. Провідними напрямками діяльності композитора були: педагогічна, видавнича, концертна і публіцистична діяльність. Основою стала педагогічна прачя мития.

Педагогічна спадщина А. Вахнянина стала вагомим здобутком у музично-педагогічному розвиткові. Вона є глибоко начіональною за змістом і свідчить про велике розуміння композитором ролі музичного мистецтва у вихованні освіченого, начіонально свідомого молодого покоління.

Ключові слова: музична освіта; начіональне виховання; педагогічна діяльність; музичне мистецтво; педагогічна спадщина; конщертна діяльність.

Jim. 9.

Ivan Frayt, Ph.D.(Pedagogy), Associate Professor of the Folk Musical Instruments and Vocals Department Drohobych Ivan Franko State Pedagogical University

Yevheniya Shunevych, Associate Professor of the Folk Musical Instruments and Vocals Department Drohobych Ivan Franko State Pedagogical University

\section{ANATOLIY VAKHNYANIN'S CONTRIBUTION TO THE DEVELOPMENT OF MUSIC EDUCATION IN EASTERN GALICIA}

Anatoliy Vakhnyanin's contribution to the development of music education in Eastern Galicia is revealed in the article. The leading directions of the composer's activity were: pedagogical, publishing, concert and journalistic activity. The basis was the pedagogical work of the artist, which by the nature and content of the work was a progressive social and pedagogical phenomenon, because it contributed to: enriching the content, forms and methods of the educational process by the national element, its scientific and methodological support; development of the idea of the Ukrainian national school and national education, establishment of its principles in practical activity; formation of an extensive network of musical societies; the establishment of the Higher Music Institute as an alternative to similar Polish and German institutions.

An important achievement of the composer's activity was the creation of the first musical societies - expressors of national interests. Thus, in the person of the "Lviv Boyan" in 1891 a society emerged, which had a decisive influence on the further development of music education and upbringing in Eastern Galicia, in particular the founding of the Higher Music Institute in 1903 in Lviv.

The pedagogical heritage of the composer has not lost its relevance at the present stage of the development of musical education in Ukraine. Subordinated to the goals of national education, it largely compensated for the lack of music teaching material for children and made a significant contribution to the theory and practice of music- 


\section{ВНЕСОК АНАТОЛІЯ ВАХНЯНИНА У РОЗВИТОК МУЗИЧНОЇ ОСВІТИ СХІДНОЇ ГАЛИЧИНИ}

aesthetic education of students. The return of the composer's spiritual heritage, the use of them in the modern school of Ukraine, will promote the development of the national idea, the formation of national consciousness of the young generations, and thus the cause of strengthening an independent state.

Keywords: music education; national education; pedagogical activity; musical art; pedagogical heritage; concert activity.

П остановка проблеми. Сучасний етап розвитку української музичнопедагогічноїнаукивимагає якнайширшого використання надбань психолого-педагогічної теорії $\mathrm{i}$ практики, а також досвіду українських педагогів минулого. Опора на досягнення прогресивних діячів минулого в галузі педагогічної науки і практики, навчання та виховання учнівської молоді в процесі розвитку національного шкільництва одна 3 головних традиційних засад української педагогіки. На потребі ї̈ раціонального використання наголошували Г. Сковорода, Т. Шевченко, Л. Українка, I. Франко, М. Грушевський та ін. На наукові пошуки, знахідки та відкриття своїх попередників творчо опиралися і рекомендували до них звертатись К. Ушинський, О. Духнович, Б. Грінченко та ін.

В історію української школи назавжди вписані імена цілого ряду педагогів, культурно-освітніх та громадських діячів, які на тому чи іншому етапі іiі розвитку активно обстоювалиї̈національний характер, своєю подвижницькою працею спричинилися до духовного відродження й утвердження українства.

До числа визначних українських педагогів, активних громадських діячів Східної Галичини другої половини XIX - початку XX століття належить i А. Вахнянин. Заслугою цього непересічного митця, прекрасного організатора музично-освітнього життя стало піднесення i актуалізування ідеї української національної музичної школи. Упродовж свого життя він залишався лідером музичного життя Галичини, твердо стояв на національних позиціях, свято вірив у щасливе майбутне українського народу $і$ шлях до нього вбачав через рідну школу і національне виховання підростаючого покоління.

Аналіз останніх досліджень та публікацій. Перші друковані праці про композитора, зокрема в другій половині XIX століття, знаходимо в таких періодичних виданнях, як “Діло”, “Зоря”, “Мета”, “Шкільна часопись” та ін.

Питання, пов'язані з діяльністю і творчим доробком А. Вахнянина знайшли помітне місце і в науково-публіцистичних працях першої половини ХХ століття (до 1939 року).

Інтерес становлять статті, дослідження, написані О. Бережницьким, М. Волошином, О. Залеським, Ф. Колессою, С. Людкевичем, К. Студинським та ін., в яких дається висока оцінка творчому доробкові композитора.
У радянський періоду музична діяльність А. Вахнянина висвітлена у працях М. Загайкевич, І. Гриневецького, в наукових публікаціях Л. Ханик, Л. Мазепи, Й. Волинського, в дисертаційних роботах Є. Штейнберг, Л. Ханик, Т. Старух, С. Процика, Л. Мазепи та іншій музикознавчій літературі.

Дещо збагатилося вивчення проблеми за останні роки. У ряді наукових праць, статтях 3 питань розвитку музичного мистецтва в Галичині знайшло своє відображення і питання музичнопедагогічної діяльності А. Вахнянина. Заслуговують наувагунаукові праці таких авторів, як М. Загайкевич, Л. Кияновська, О. Михайличенко, С. Павлишин, С. Сухорський, I. Фрайт, М. Черепанин та ін.

Мета статті - виявити внесок Анатолія Вахнянина у розвиток музичної освіти Східної Галичини.

Виклад основного матеріалу. Серед провідних галицьких композиторів другої половини XIX початку XX століття Анатолій Вахнянин посів одне 3 найпочесніших місць. Видатний композитор, педагог, визначний музичногромадський діяч, він залишив яскравий слід в українській музичній культурі. Його ім'я, як справедливо відзначає С. Людкевич, "не зникне з історії нашої культури і мусить увійти до пантеону української музики" $[5,3]$.

Народився Анатолій Вахнянин 7 вересня 1841 року в с. Сінява (тепер місто Жешувського воєводства, Польща) в сім'ї священика. Закінчивши початкову школу і гімназію в Перемишлі (1859), майбутній композитор вступив до Львівської духовної семінарії, не полишаючи заняття музикою.

У гімназії А. Вахнянин навчався музики у чеських музикантів: співу - у Вікентія Серсаві і Франтішека Лоренца, а гри на скрипці - у Людвіга Седлака. Однак це навчання мало переважно німецький характер. Згадуючи його, А. Вахнянин писав: “На т. зв. "Singstund-ax”, тричі в тиждень, співали ми легенькі квартети виключно німецьких авторів $[1,125]$, а $з$ учнів "роблено медія для поширення німецької пісні” $[2,126]$.

Необхідно відзначити, що музиканти в колишній колонії Габсбургів - Галичині, як правило, були приречені на злидарське існування, тому талановита молодь мусила обирати більш “достойні професії”, як от сан священика. Саме ця обставина, а також сімейні традиції змусили 
А. Вахнянина вступити до духовного закладу. Однак, як відомо, композитор усе своє подальше життя присвячує музиці.

Світогляд А. Вахнянина формувався під впливом ідей Т. Шевченка. Майбутній композитор, будучи на той час вихованцем Львівської духовної семінарії, цікавиться музикою, літературою, мистецтвом. Особливо велике враження на нього мали музичні композиції М. Вербицького та І. Лаврівського, які глибоко западали в його душу і збуджували національну свідомість. Саме у Львівській духовній семінарії у 1862 році композитор написав свій перший хоровий твір на слова Ю. Федьковича “Чи знаєш, де країна наша мила?".

Активна музично-педагогічна діяльність А. Вахнянина розпочинається 1863 року, коли він переїхав до Перемишля і останній, четвертий, курс навчався у Перемиській духовній семінарії. Тут майбутній композитор створив з учнів товариство "Громада", а при ньому і гурток для навчання співу. Це товариство, завдяки А. Вахнянинові, відіграло помітну роль у музичному житті Перемишля. “В мурах семінарії, - писав А. Вахнянин, - залунала вперше козацька пісня “Ой Січ мати”, “Ой став пугач на могилі” [2, 49], a в кімнаті композитора “виголошували Шевченкові твори та співали пісні, що їх склав Маркил Лаврівський на основі збірника пісень А. Коціпінського" [7, 4].

Закінчивши духовну семінарію, А. Вахнянин працює два роки вчителем української мови в Перемиській гімназії. Саме в цьому закладі він відстоює права на існування української мови i літератури. Крім того, і надалі керує хором "Громада", в якому основним дидактичним матеріалом стають музичні твори М. Вербицького та I. Лаврівського. Однак, композиторові доводиться долати великі труднощі, які чинив австрійський уряд, що у своїй політиці онімечення намагався використати і музичне мистецтво. Такий опір А. Вахнянин зустрів при організації концерту, присвяченого четвертим роковинам смерті Т. Шевченка. Проте, незважаючи на перешкоди, які здійснювало австрійське керівництво, що боялося живого слова великого поета, концерт завдяки А. Вахнянинові відбувся 10 березня 1865 року і пройшов з великим успіхом.

Цей виступ, який увійшов до історії української музики як перший в Галичині концерт, присвячений пам'яті Т. Шевченка, знайшов широкий відгук у містах краю. Серед творів, що прозвучали на ньому, були композиції I. Лаврівського “Корона золотая”, “Заспівай ми, соловію”, “Сумно-марно”, “Чом річенько”;
М. Вербицького “Послухай”, а також його знаменита композиція “Ще не вмерла Україна", яка відразу ж стала національним гимном нашого народу. Прозвучала там і композиція А. Вахнянина "Колись було" та інші твори. Концерт перетворився на велику маніфестацію українства, на яку відгукнулися різні часописи.

Таким чином, заслуга в організації та проведенні першого Шевченківського концерту в Галичині належить А. Вахнянину. Цей виступ дав поштовх до проведення щорічних шевченківських свят у багатьох містах і селах регіону. Його ж підготовка та проведення давали наставникам невичерпний виховний матеріал і ставали ефективним засобом зміцнення національної свідомості української молоді.

У 1865 році А. Вахнянин вступив до Віденського університету на відділ історії та географії, де продовжує і надалі культивувати українське музичне мистецтво. Зокрема, у березні 1866 року, завдяки його діяльній участі відбувся перший Шевченківський концерт у Відні. Серед творів, які прозвучали на ньому, була і композиція М. Вербицького “Ще не вмерла Україна”, а також хор І. Лаврівського "Чом, річенько, домашняя". Крім того, саме А. Вахнянином були відспівані дві пісні М. Вербицького “Колись було” i “Послухай”, які викликали велике захоплення слухачів. "Кожний кусник мусів він по два рази співати, бо оплески не хотіли доти переставати, доки не повторив п. Вахнянин” [7, 8].

Велика заслуга А. Вахнянина і в організації для української молоді у Відні на початку 1868 року товариства “Січ”. Його заснування було спричинено тим, що багато слов'янських студентів різних народностей мали вже у Відні свої товариства: чехи - “Славію” та "Моравію”; словаки - “Татран”; хорвати - "Велебіт”; серби - “Зорію”; болгари - “Балкан”; поляки “Огніско”. “Тільки ми, русини, - писав А. Вахнянин, - блукали по полі, як вівці” $[7,8]$.

Поява на ниві національного життя українців у Відні товариства “Січ”, основною метою якого було “сходитися з слов’янськими студентами i репрезентувати поміж ними Русь нашу як окремий народ, знайомити їх 3 нашою мовою і нашою піснею та літературою" $[2,74]$, мало неабияке значення для загальноосвітнього і культурного піднесення українців Галичини, а також дало поштовх до заснування в грудні 1868 року в Львові товариства "Просвіта".

Це товариство, ініціатором заснування i першим головою якого був А. Вахнянин (у грудні 1868 року, склавши екзамен у Відні, він переїжджає до Львова), стає культурно-освітнім центром, 
навколо якого, поряд із урядниками, студентами, духовенством і вчителями початкових та середніх шкіл, гуртуються й композитори, які стають його членами.

Вважаючи музичний спів “добрим засобом пробудження національної свідомості” [2, 112], А. Вахнянин у 1870 році засновує товариство “Теорбан”, де за статутом передбачалась музично-освітня діяльність. При ньому існувала музична школа для вивчення інструментальної, вокальної музики, гармонії і контрапункту, в якій вчителем був відомий польський композитор I. Гунєвич. Він, як стверджує А. Вахнянин, дав і йому “перші відомості про гармонію ... і заохотив ... до композиції” [2, 112]. Однак через відсутність матеріальних коштів і приміщення це товариство, яке існувало на приватній ініціативі композитора і було розміщене в його будинку, не проіснувавши $\mathrm{i}$ року, припинило свою діяльність. Проте, навіть короткотривале існування "Теорбана", стало помітним внеском у розвитку української музичної культури регіону.

Аналізуючи діяльність А. Вахнянина в 70-х роках XIX століття, слід відзначити, що вона мала систематичний та цілеспрямований характер і була спрямована на утвердження ідеї національного відродження. Працюючи від 1870 року учителем історії та географії в Академічній гімназії Львова, він організовує в цьому закладі хор, який стає одним із найкращих серед учнівських колективів краю. Крім цього, композитор був членом комісії з впорядкування і видання різних підручників для народних та середніх шкіл.

У липні 1871 року композитор виступив на з'їзді польського педагогічного товариства, на якому неодноразово наголошував про значення української народної пісні для нашого народу. Ця доповідь була надрукована в часописі "Основа" за 1871 рік, Ч. 83-85.

3 тодішніх публіцистичних праць А. Вахнянина особливої уваги заслуговують “Листи про музику”, опубліковані в часописі “Правда” за 1873 рік, Ч. 8. Це ще раз підтверджує той факт, що композитор у своїй музично-освітній діяльності все частіше звертається до музичного мистецтва як одного з важливих чинників у боротьбі за народну освіту і педагогіку.

Саме з 70-х років XIX століття, розпочавши свою роботу над оперою “Купало”, А. Вахнянин після її завершення увійшов у історію української музики як автор першої української опери в Галичині. Хор Академічної гімназії, в якому “співали тоді... добрі співаки: молоденький Закревський (майбутній оперний артист) та інші молоді хлопці" [2, 112], досить часто, виступаючи на концертах, виконували різні фрагменти з цього твору. Зокрема, 23 березня 1876 року за ініціативою товариств “Академічний кружок” і “Дружній лихвар” у Львові відбувся концерт на допомогу бідним учням гімназії, на якому під керівництвом А. Вахнянина були виконані уривки 3 його опери.

У 80-х роках XIX століття А. Вахнянин продовжує і надалі працювати керівником учнівського хору в Академічній гімназії, постійно турбується про репертуар колективу і прагне до демократизації навчально-виховного процесу. Його форми і методи виховання сприяли вихованню правильних естетичних поглядів учнів. Про високий професійний рівень хору свідчать численні концерти і позитивні відгуки в періодичних виданнях. Про один із них, який відбувся на честь приїзду цісаря Франца Йосифа до Львова, часопис “Діло” писав: “Коли цісар вступив до гарно прибраного залу, відізвався на його привітання святковий, милозвучний i одушевляючий спів “гімну народного” (австрійського - І. Ф., С. Ш.), який відспівав добрий хор учнів української гімназії під керівництвом проф. Вахнянина" $[8,1]$.

Відсутність дидактичного матеріалу для навчання співу змушує композитора заповнити цю прогалину. У 1885 році він разом із П. Бажанським видає збірник хорових квартетів “Кобзар", який, поряд із виданням “Боян" В. Матюка, опублікованим у 1884 році, широко використовувався учнівськими хоровими колективами.

А. Вахнянин у своїй педагогічній праці важливого значення надавав українській народній пісні. У передмові до “Кобзаря” він писав: “Наша пісня нехай будить руську долю, нехай двигне нас до життя! В щастю - нехай буде гімном похвальним, в недолі - відрадою, а в боротьбі нехай стане голосним покликом на бій за волюдолю народу... " [4, VII].

Крім керівництва хором, А. Вахнянин займає посаду вчителя історії та географії. Саме для цього предмету він у 1884 році видав "Учебник географії для шкіл середніх", який використовувався у практичній діяльності вчителів цього предмету, а також видає у 1889 році “Співаник церковний для шкіл народних”. Мабуть, у цей час ним були написані “Співанки шкільні”, куди увійшло 16 нескладних пісень на 2, 3, і 4 голоси.

А. Вахнянин є також автором праці “Наука гармонії”, рукопис якої зберігається в Центральному державному історичному архіві 


\section{ВНЕСОК АНАТОЛІЯ ВАХНЯНИНА У РОЗВИТОК МУЗИЧНОЇ ОСВІТИ СХІДНОЇ ГАЛИЧИНИ}

Львова. У цій праці він синтезував основні положення музичної науки з метою пропаганди музичних знань не тільки серед учнів, а й учителів і аматорів цього виду мистецтва.

Таким чином, педагогічна спадщина А. Вахнянина стала вагомим здобутком у музично-педагогічному розвиткові. Вона $є$ глибоко національною за змістом і свідчить про велике розуміння композитором ролі музичного мистецтва у вихованні освіченого, національно свідомого молодого покоління.

Публіцистична діяльність композитора у 80-их роках XIX століття за обсягом невелика. Вона представлена статтею “Дмитро Бортнянський”, яка опублікована в часописі “Діло”, 1886 рік, Ч. 35-36, і рецензіями на "Учебник початкових відомостей музики і співу” І. Кипряна та “Руский співаник для шкіл народних” В. Матюка.

У першій рецензії композитор писав, що потреба такого видання у нас відчувалась дуже давно. I хоч В. Матюк у 1884 році запропонував Шкільній Раді рукопис такого ж підручника, однак якось важко було цій праці побачити денне світло. “А тут, - продовжує автор, - без оголошення i власним фондом прийшов на допомогу своєму народові бідний завідатель “турецького (турківського-І.Ф., Є.Ш.) повіту”. Проаналізувавши "Учебник початкових відомостей музики і співу" I. Кипряна, А. Вахнянин пише, що “його сміло можна рекомендувати нашим землякам" $[3,4]$.

У рецензії на "Руський співаник для шкіл народних” В. Матюка, даючи йому позитивну оцінку, композитор писав: “відзначається систематичністю, починається вправами на прімах, секундах аж до октав, і всюди використовує пісні..." [6, 4].

Таким чином, можна стверджувати, що А. Вахнянин був добре обізнаний зі станом викладання музики, а також з підручниками, що були видані в цей період. Саме тому і щиро радів 3 появи подібних видань, які сприяли утвердженню національних основ музичного навчання i виконання.

Не менш важливу роль у розвитку музичної освіти та виховання у 80-х роках XIX століття відіграла концертна діяльність А. Вахнянина, де звуки рідної пісні, палкі слова, звернуті до народу, впливали на свідомість і кликали на боротьбу за національне відродження.

Крім щорічних шевченківських концертів у 80-х роках у Галичині проводяться ювілейні виступи, присвячені пам'яті М. Шашкевича, І. Котляревського, які перетворюються на справжню маніфестацію українського народу. Показовим щодо цього $\epsilon$ концерт, який відбувся 2 лютого 1888 року в
“Народному Домі” на честь М. Шашкевича. Промова на ньому А. Вахнянина ще раз підтвердила важливість української народної пісні в боротьбі за національне відродження регіону. “Як на віщі слова Тараса на зеленій Україні трупи встали і очі відкрили, і брат з братом обнялись і проговорили слова тихої любові, так і на землі Даниловій від русальної пісні повіяло чарами, від котрих народ нога в ногу став до праці біля свого національного відродження" [9, 1], - відзначав композитор у своєму виступі.

Концертна діяльність А. Вахнянина у 80-х роках XIX століття стала однією з важливих форм музичного виховання, яка мала великий естетичний вплив на широкі кола суспільності і сприяла утвердженню українського музичного мистецтва.

Якісно новим періодом у діяльності композитора є 90-і роки XIX століття, що пов'язані 3 заснуванням музичних товариств “Боян”. Ці об'єднання стають творчою лабораторією, де питання мистецького навчання і виховання набувають особливої актуальності.

Важливо відзначити, що виникнення “Львівського Бояна", яке стало поштовхом для заснування багатьох подібних хорів в інших містах регіону, було підготовлена всім ходом суспільнополітичного і культурного життя. Серед першопричин його появи стали професійні проблеми, пов'язані, передусім, з відсутністю музичного закладу для галицького населення. Незаперечним $\epsilon$ той факт, що заслуги А. Вахнянина в організації цього товариства $є$ справді вагомі. Історична роль “Боянів" полягає ще й в тому, що вони мали вирішальний вплив на заснування у 1903 році Вищого музичного інституту у Львові.

Першим директором інституту став А. Вахнянин, який у вересні 1903 року оголосив набір за спеціальностями: музичної композиції; сольного співу; хорального співу; гри на фортепіано; гри на скрипці та інших оркестрових інструментах. Цей заклад, в якому А. Вахнянин працював до кінця своїх днів (помер 11 лютого 1908 року), став одним із провідних, в якому продовжували і розпочинали свою діяльність чимало галицьких композиторів. Саме в ньому формується новий тип композитора-професіонала, який згодом, ставши педагогом, значно розширить сфери музичного шкільництва.

Висновки. Становлення А. Вахнянина як педагога, культурно-освітнього діяча, організатора музично-навчальних інституцій відбувалося під впливом суспільно-політичних, соціальноекономічних, культурно-освітніх процесів. 
Історичні процеси закономірно відбились на світогляді й подальшій музично-освітній діяльності композитора.

На формування світогляду, інтелектуальний та духовний розвиток А. Вахнянина вплинули такі головні чинники, як життя серед рідного народу, за яким - багатовікові, світового значення історичні й культурні здобутки; творчі зв'язки з відомими композиторами, письменниками, педагогами, політичними діячами; пізнання європейської культури, прогресивних музичнопедагогічних ідей.

Провідними напрямками діяльності А. Вахнянина були: педагогічна, видавнича, концертна i публіцистична діяльність. Основою стала педагогічна праця митця. Саме у ній відображена позиція композитора $з$ питань відродження української національної школи: наповнення національним змістом музично-педагогічної теорії та практики, удосконалення національного виховання молоді.

\section{ЛІТЕРАТУРА}

1. Бережницький О. Наші музики. Артистичний вісник. Львів, 1905. Зош. 9-10. С. 124-131.

2. Вахнянин А. Спомини з життя. Львів, 1908. $138 \mathrm{c}$.

3. Вахнянин А. Учебник музики і співу. Діло. 1885. Ч. 16. C. 4.

4. Вахнянин А., Бажанський П. Кобзар. Львів, $1885.114 \mathrm{c}$.

5. Людкевич С. Анатолій Вахнянин (до 20річчя від дня смерті). Діло. 1928. Ч. 115. С. 3.

6. Наука, штука і література. Діло. 1886. Ч. 49. C. 4 .
7. Студинський К. Чехи в спогадах Анатоля Вахнянина. Львів, 1936. 15 с.

8. Цісар Франц-Іосиф в російській академічній гімназії. Діло. 1889. Ч. 69. С. 1.

9. Ювілейний вечір Маркіяновий. Діло. 1888. Ч. 19. С. 1-2.

\section{REFERENCES}

1. Berezhnytskyi, O. (1905). Nashi muzyky [Our music]. Artistic Bulletin. Lviv. Zost 9-10, pp.124131. [in Ukrainian].

2. Vakhnianyn, A. (1908). Spomyny z zhyttia [Memories of life]. Lviv. [in Ukrainian].

3. Vakhnianyn, A. (1885). Uchebnyk muzyky i spivu [Music and singing tutorial]. Work. Lviv. Part16, p. 4. [in Ukrainian].

4. Vakhnianyn, A. \& Bazhanskyi, P. (1885). Kobzar [Kobzar]. Lviv. [in Ukrainian].

5. Liudkevych, S. (1905). Anatolii Vakhnianyn (do 20-richchia vid dnia smerti) [Anatoly Vakhnyanin (to the 20th anniversary of his death)]. Work. Lviv. Part 115, p. 3. [in Ukrainian].

6. Nauka, shtuka i literatura (1886). [Science, science and literature]. Work. Lviv. Part 49, p. 4. [in Ukrainian].

7. Studynskyi, K. (1936). Chekhy v spohadakh Anatolia Vakhnianyna [Czechs in the memoirs of Anatoly Vakhnyanin]. Lviv. [in Ukrainian].

8. Tsisar Frants-Iosyf v rosiiskii akademichnii himnazii (1889). [Cesar Franz-Joseph in the Russian academic high school]. Work. Lviv. Part 69, p. 1. [in Ukrainian].

9. Iuvileinyi vechir Markiianovyi (1936). [Markiyanov Anniversary Evening]. Work. Lviv. Part 19, pp. 1-2. [in Ukrainian].

Стаття надійшла до редакції 09.01.2020

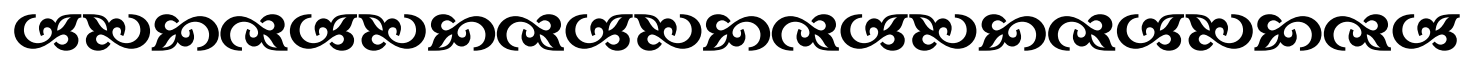

“Життя, здається, йде без зусиль, коли я наповнений музикою”.

$$
\text { DжорджЕліот }
$$

англійська письменниия

\author{
"Фивне мистецтво - музиқа - найпоетичніше $і$ найточніше з усіх мистеитв, \\ розпливчасте, яксон і точне, якалгебра". \\ Ti de Monacсан \\ франиузький письменник \\ "Хто хоче Багато досягти, повинен ставити великі вимоги". \\ Йоганн Вольббанг бон Тете \\ німеиький поет, прозайк, драматург
}

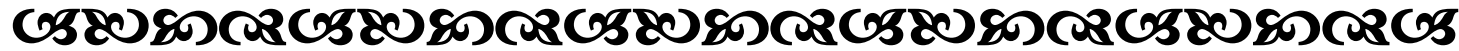

